\title{
Trajectory: A model of the sign and of semiosis
}

\author{
Winfried Nöth ${ }^{1}$
}

\begin{abstract}
This paper examines how far the model of the trajectory as a path that a moving object follows from a source to a goal is an adequate model of the sign and of semiotic processes. Just like intentions, meanings, and messages, also signs have sources and goals. A study of the terms by which the Ancient Greeks referred to signs (sêma, semeîon, and tekmérion) reveals that the idea of goal-directedness is inherent in several respects in this early semiotic vocabulary. The paper studies Charles S. Peirce's model of the sign as a trajectory by which Peirce describes the "agency of the sign". Peirce's semiotic trajectories are without beginnings and ends. Guided by final causality towards a semiotic goal, the sign can reach its goal only by asymptotic approximation. The final section of the paper presents brief notes on the trajectories characteristic of sign processes in semiotic models outlined by Algirdas Greimas and Juri Lotman. Greimas distinguishes a plurality of semiotic trajectories, such as the generative, the thematic, and the figurative one, but the prototype of all trajectories is the narrative one. Bifurcations resulting from conflicting tensions interrupt the unilinearity of the goal-directed trajectories. Besides disjunctions, the model foresees conjunctions in which trajectories merge. The dynamic forces that propel the agents (subjects and objects, agents and patients, senders and receivers, heroes and villains) along such trajectories are polar tensions and conflicts as well as phases of desire and fulfilment. Lotman proposes a dynamic model of human culture as a semiotic space where sign processes occur like "rushing torrents" or even take the form of "explosions", suggesting trajectories whose characteristics are nonlinearity, bifurcation, sudden interruption, and unpredictable reorientation. Concomitant with such trajectories are the bidirectional trajectories that describe the dynamic relations between the centre and the periphery of a cultural semiosphere.
\end{abstract}

Keywords: trajectory; sign; semeîon; sêma; Charles Peirce; Algirdas Greimas; Juri Lotman

1 Programa de Estudos Pós-Graduados em Tecnologias da Inteligência e Design Digital, Pontifícia Universidade Católica de São Paulo, Rua Caio Prado, 102 - Consolação, CEP 01303000 São Paulo, Brazil; e-mail: wnoth@pucsp.br. 


\section{Trajectories as semiotic processes}

Trajectories are in many ways at the root of signs and of processes of semiosis. Signs are closely associated with intentionality, and intentionality with goals or targets. A projectile follows a trajectory before it reaches its target. A sender of a sign has an intention, a goal, too. A trajectory is the path that a moving object follows as it moves towards its target. A sender emits signs, whereas a missile emits a projectile from a starting point towards a target point.

Signs convey meaning. To mean is also to aim at a target. The Old English verb monan meant simply 'to intend'. A sign emitted by a sender aims at the receiver's mind. A projectile aims at its target. To communicate as well as to mean is to have a goal. Aiming at her goal, the sender's intention describes a trajectory from its starting point to its target.

One who has a goal needs to embark upon a path to reach a goal, but a trajectory is not a path. It reaches its goal in a curve projected through space, whereas a path is trodden on flat ground. Paths are trodden on the surface of a two-dimensional plane, whereas a trajectory course goes through three-dimensional space. The notion of a trajectory has clearly technological, if not military, connotations. It has connotations of dynamics, which the word meaning does not necessarily have.

Trajectories result from projections of objects into space. The notion of projection again implies a purpose. Projects are plans. Both concepts, projection and trajectory, have their root in the Latin word iacere, 'to throw', 'to fling forth', 'to cast out. This root conveys the notion of a trajectory its dynamic connotation. Sign processes are dynamic processes so that their association with trajectories is no wonder.

In English, trajectory is also a technical term of astronomers. In their jargon, a satellite 'describes a trajectory' when it follows its course. The expression mixes astronomy with semiotics quite literally, since 'to describe' means 'to write down verbal signs'. Not only the planets but also the astronomers describe trajectories. The astronomers' descriptions are the iconic graphic representations of the trajectories of celestial bodies.

\section{The notion of sign in Ancient Greece}

The idea of a sign among the ancient Greeks was narrower than the one in modern languages today, but the image of a trajectory can be found very early in the vocabulary of Classical Greek. The earliest notion of sign was the one of an index, a mark in the landscape. "Before Parmenides, a sign $(\sigma \tilde{\eta} \mu \alpha)$ was mainly 
a military order, a landmark, a portent, or memento" (Meier-Oeser 1997: xvi). Homer used the noun sêma ( $\sigma \tilde{\eta} \mu \alpha)$ and the verb semaino ( $\sigma \eta \mu \alpha i v \omega)$ when signs were his topic. A sêma is a 'mark', a 'characteristic', an 'indication' as well as an 'omen' or 'portent' (Castañares 2014). These are kinds of indexical signs. An index shares the dynamics of semiosis in a peculiar way. It attracts or "forces the attention to the particular object intended" (W 5:243, 1885), or "takes hold of our eyes, as it were, and forcibly directs them to a particular object, and there it stops" (W 5: 163, 1885). The index is thus an attractor, source and goal of a trajectory at the same time.

The law that like attracts like is also applicable to signs. They attract each other in semiotic processes called associations. Sêma, in Homer's epic writings, could also mean 'grave', 'tomb', or 'gravestone.' Now, sêma is in a relation of consonance with the word sôma $(\sigma \tilde{\omega} \mu \alpha)$, which means 'human body'. With this in mind, Plato, in his Cratylus, reminds us that some have called human bodies the tomb (sêma) of their souls:

Socrates: You mean soma $[\sigma \tilde{\omega} \mu \alpha]$, the body. [...] That may be variously interpreted; and yet more variously if a little permutation is allowed. For some say the body is the grave, sema ( $\sigma \tilde{\eta} \mu \alpha)$, of the soul, which may be thought to be buried in our present life; or again the index $(\sigma \tilde{\eta} \mu \alpha)$ of the soul, because the soul gives indications to ( $\sigma \eta \mu$ aiveı [semaínei]) the body. (Plato 400b-c, trans. Jowett)

The similarity between the sounds of sêma and sôma results also in an attraction of one meaning by the other. The notion of the tomb is attracted by the notion of the sign. The trajectory of the transfer reaches the meaning of the sign and enriches it with the notion of the image of a soul in a body.

The association of sêma with sôma anticipates the currently much debated issue of the embodiment of the sign, which is also a Peircean theme. Two of his types of sign are in a way bodiless, the symbolic legisign and the iconic qualisign, whereas genuine indices are always embodied. A symbol is not a material object; it is an immaterial semiotic law, but one which produces bodies or has embodiments in writing or speech. The qualisign, too, is bodiless since it is only the possibility of a sign. When it is really embodied, it turns into a sinsign. The dynamics of embodiment implies trajectories from the bodiless to the embodied.

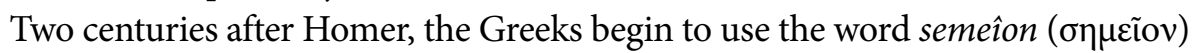
in addition to sêma. A semeîon is a mark, a badge, a seal or signet, a signal, a proof, or anything 'from which something else may be recognized'. In such connotations, the idea of indexicality continues to be predominant.

Another sign concept among the Greeks was sýmbolon ( $\sigma \dot{\mu} \mu \beta \mathrm{o} \lambda \mathrm{ov}$ ). Initially, it also had the senses of a 'mark', a 'characteristic', or 'indicator'; later, it acquired 
the sense of a 'sign by mutual agreement', hence a 'symbol' in the modern sense. Etymologically, the word 'symbol' derives from syn ( $\sigma \dot{v} v)$ 'together' and bállō ( $\beta \dot{\alpha} \lambda \lambda \omega)$, 'I throw'. The association with the idea of 'throwing things together' apparently by joining signifiers with signifieds - suggests two trajectories coming from opposite directions meeting in the middle. Etymologically, a symbol is a token made by two persons for the purpose of identifying each other in the future. Before a journey to distant places, friends had the custom of splitting an object into two and keeping the halves for the purpose of identifying each other in the distant future when one might not recognize the other anymore otherwise.

A further dynamic sign conception among the Greeks appears in the word tekmérion and its cognate tékmar. Aristotle, in the first book of his Rhetoric (1357b-1358a) distinguishes between the tekmérion as a certain, necessary, or infallible sign and the uncertain, weak, refutable, or fallible sign, to which he gives no specific name (anónimon). Uncertain were also the meanings conveyed by the Oracle of Delphi, of which Plutarch reports that it "neither speaks nor conceals but signifies", i.e., semainei ( $\sigma \eta \mu a i v \varepsilon ı)$. Thomas A. Sebeok (2001: 145) once concluded from this quote that the utterer of these oracles, the priestess Pythia, was the first female semiotician.

The Greek words whose meaning comes closest to the concept of a semiotic trajectory are tékmar ( $\tau \dot{\varepsilon} \kappa \mu \alpha \rho$ ) or tékmor, cognates of tekmérion. The meaning is 'fixed mark, 'boundary', 'goal', 'end', 'purpose'. Like tekmérion, tékmar was a certain sign, for example, 'a token of some high and solemn kind', 'a sign in heavens', or 'of the moon'. Aristotle says that 'tékmar' means the same as 'péras', 'utmost limit', 'end' (Rhetoric I, 1357b 9), but he attributes this insight to "the Ancients" (cf. Castañares 2014: 19). It was only four decades ago that Marcel Detienne and Jean-Pierre Vernant were able to reveal, in their book Cunning Intelligence in Greek Culture and Society (1978), what Aristotle must have meant by those "Ancients" who associated signs with the notion of an utmost limit. The authors argue that Aristotle refers with these words to an Ancient Greek cosmogony (re)discovered only in 1957. Written by the Spartan poet Alcman in the 7th century BC, this mythical narrative explains the origins of the world by means of a semiotic scenario whose protagonists are Thetis, the great goddess of the Sea, and her acolytes with the telling names Tékmōr ('sign', 'index', 'guide mark'), Póros ('path'), and Skótos, the personification of darkness. According to Detienne and Vernant,

The function of Tekmōr and Póros appears to be to dissipate the darkness personified by Skótos and to open up the routes by which the Sun can come, bringing the light of day as it moves along while the shining paths of the constellations appear on the vault of the sky. Within the expanse of the sea where they exercise their 
powers, Guide mark and Path, Tékmōr and Póros, are the terms which define the activity of an intelligence entirely directed towards escaping from the aporia of a world dominated by confusion. Póros [...] means the stratagem or expedient [...] to open up a path. As for Tékmōr, which means not only the goal aimed at but also the plan or remedy to cope with a difficult situation, it is a concept which relates to the intersection of three separate but complementary domains, namely navigation, astronomy and divination. In the context of navigation Tékmōr means the end of the journey; the point on the horizon which serves to orientate the course of the ship. [...] To navigate by following the guide-marks fixed in the sky is also to trust in the signs sent by the gods and revealed through the intermediary of a diviner. It is divination which reveals to the pilots the shining signs on the basis of which they will 'conjecture' (tekmaíresthai) their itinerary by recognizing signals and choosing guide-marks in such a way as to construct a bridge between the visible and the invisible. (Detienne; Vernant 1978: 288)

The origins of our world, according to this mythical trajectory, are thus due to an interplay of semiotic forces fighting against the antisemiotic powers of darkness. The scenario is one of navigating ships whose guidance requires "conjectures", i.e., the reading of signs, to find the right trajectory. The end of which Tékmōr, alias Sign, is the synonym, according to Aristotle, is the navigator's distant goal, the sign's final cause. The signs that indicate the mythological trajectory have to be

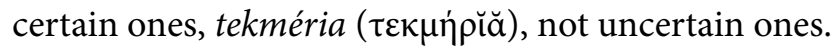

\section{The Peircean sign as a trajectory}

The insight that the trajectory does not connect its source and its goal in the form of the geometrically more economic straight line, but in the longer trajectory of a curve is reminiscent of Charles S. Peirce's conception of semiosis as a process in which signs have a "final cause or end". The final cause or purpose of a sign is to produce an interpretant in its interpreter. In contrast to an efficient cause, which operates immediately or mechanically, a final cause may reach its goal by detours. The sign's trajectory from their source in the object to their goal in the interpretant does not need to be direct. Like God, of whom the proverb says that he writes straight with crooked lines, the path by which a sign reaches its goal may be curved or even crooked. Peirce describes this aspect of semiosis as follows:

We must understand by final causation that mode of bringing facts about according to which a general description of result is made to come about, quite irrespective of any compulsion for it to come about in this or that particular way; although the means may be adapted to the end. The general result may be brought about at one time in one way, and at another time in another way. Final causation 
does not determine in what particular way it is to be brought about, but only that the result shall have a certain general character. (CP 1.211, 1902)

The trajectory that the Peircean sign describes from its source to its goal is not the trajectory of a message that has its source in the mind of a sender and reaches its goal in the mind of a receiver. The agents and patients in the scenario of semiosis are not senders and receivers, but the Sign, its Object, and its Interpretant. Notice the spelling of these protagonists in capital letters, when Peirce describes the scenario:

In every case an influence upon the Sign emanates from its Object, and [...] this emanating influence then proceeds from the Sign and produces, and is capable of producing and partly at least, in a mental way, and effect that may be called the Interpretant, or interpreting action, which consummates the agency of the Sign. (MS 643: 23; 1909)

A trajectory that goes parallel with the trajectory of semiosis is the one of the time line from the beginning to an end. The time line of the agency of the sign does not begin in the mind of a sender; it begins with the Object insofar as it determines the Sign to represent it and to create an interpretant. The sign itself, alias representamen, is the second agent in the scenario. From the sign, the message moves on to, and thirdly reaches, its destination in the interpretant.

At first glance, the semiotic time line "object $\rightarrow$ sign $\rightarrow$ interpretant" sounds incompatible with Peirce's system of the three categories. For the Object is a phenomenon of Secondness, so that semiosis seems to begin with Secondness and not Firstness. However, this beginning in Secondness refers only to the line of causality in semiosis. The Object determines the Sign, and the Sign the Inerpretant.

From the perspective of interpreting signs, the Sign comes first and the Object second. The interpreter is first faced with the Sign, not yet its Object. At this first moment, the Sign is still a mere possibility of interpretation. The Object, which the Sign represents, comes second when it is evoked in the interpreter's mind by the Sign. The Interpretant comes third in line because it presupposes the object and the sign.

In this scenario, the sign is an autonomous agent in the process of semiosis. The so-called producers and consumers of signs are their masters. After all, the signs are not theirs; not they have invented them. Peirce is very radical in this affirmation, attributing to the sign the role of a real agent. In 1901, he wrote, "every symbol is a living thing, in a very strict sense that is no mere figure of speech" (CP 2.222). A year later, he even affirmed that symbols actually live, "that 
there not only may be a living symbol, realizing the full idea of a symbol, but even that there actually is one" (CP 2.114; 1902; emphasis added).

The trajectory of the sign has another peculiarity, its incompleteness. The purpose of the sign to represent its object remains always incomplete. A sign that reaches its goal to represent its interpretant would be a final interpretant, but no interpretant can ever aspire to being final. It can only be approached more and more closely, never really actually. This scenario describes the trajectory of the Sign as an asymptotic line:

Philosophy tries to understand. In so doing, it is committed to the assumption that things are intelligible, that the process of nature and the process of reason are one. Its explanation must be derivation. Explanation, derivation, involve suggestion of a starting-point - starting-point in its own nature not requiring explanation nor admitting of derivation. Also, there is suggestion of goal or stopping-point, where the process of reason and nature is perfected. A principle of movement must be assumed to be universal. It cannot be supposed that things ever actually reached the stopping-point, for there movement would stop and the principle of movement would not be universal; and similarly with the starting-point. Starting-point and stopping-point can only be ideal, like the two points where the hyperbola leaves one asymptote and where it joins the other. (CP 6.581)

\section{Notes on Greimassian and Lotmanian trajectories}

Research in the trajectories characteristic of the diverse models of semiosis is a desideratum for semiotics. Only a very brief glimpse of two further models is possible here, the ones by Greimas and Lotman. Trajectory is a key concept in Greimas's text semiotics. Its author distinguishes several types of trajectories, the generative, the narrative, the thematic and the figurative trajectory. Defined as having a direction from a source ( $a b$ quo) towards a goal (ad quem), Greimas's trajectories often seem to be of the nature of a linear path, at least insofar as they are inspired by the narrative time lines of Propp's folk tales. Of course, the lines are never straight. There are often bifurcations resulting from tensions that interrupt the lines from the beginning, the trajectory's source, to the end, when the goal is reached. Besides disjunctions, the model also foresees conjunctions in which trajectories merge. The dynamic forces that propel the agents (subjects and objects, agents and patients, senders and receivers, heroes and villains, seekers vs. sought-after) along such trajectories are polar tensions and conflicts as well as phases of desire and fulfillment. Greimas had the vision of extending the linearity of his trajectories into the space, when he wrote: 
The term trajectory ought to be extended in use progressively until it implies not only a linear and directed disposition of the elements between which it occurs but also a dynamic perspective suggesting a progression from one point to another by way of intermediate domains. (Greimas, Courtés 1986: 347)

Although 'trajectory' is not a key concept of Lotman's semiotics, his conception of the semiosphere can be read as a sphere with trajectories of a spatial type. The space is the universe of semiosis, which he defines as a Semiosphere (Lotman 1990). Its trajectories have centres and peripheries between which there is a dynamics of tension, conflict, and exchange. Later, Lotman proposes the dynamic model of a human culture whose evolution he first characterizes by the metaphor of a 'rushing torrent' and later by the one of 'explosion' (Lotman 2009). The trajectories implied in such models of cultural semiosis are nonlinear with bifurcations, sudden interruptions, and unpredictable reorientations. In contrast to the scenario of chaos, albeit creative, suggested by the metaphor of explosion, Lotman's conception of a culture as a semiosphere characterized by tensions between the centre and the periphery is one of a space structured by bipolar attractors.

\section{References}

Aristotle 1909. Rhetoric (Jebb, Richard Claverhouse, trans., ed., intr.). Cambridge: Cambridge University Press.

Castañares, Wenceslao 2014. Historia del pensamiento semiótico. Madrid: Trotta.

CP $=$ Peirce, Charles S. 1931-1958. Collected Papers of Charles S. Peirce (vols. 1-6, Hartshorne, Charles; Weiss, Paul, eds.; vols. 7-8, Burks, Arthur W., ed.). Cambridge: Harvard University Press. [In-text references are to CP, followed by volume and paragraph numbers.]

Detienne, Marcel; Vernant, Jean-Pierre 1978[1974]. Cunning Intelligence in Greek Culture and Society. (Lloyd, Janet, trans.) Hassocks: Harvester.

Greimas, Algirdas J.; Courtés, Joseph 1986[1979]. Semiotics and Language: An Analytical Dictionary. (Christ, Larry; Patte, Daniel et al., trans.) Bloomington: Indiana University Press.

Lotman, Yuri M. 1990. Universe of Mind: A Semiotic Theory of Culture. (Shukman, Ann, trans.) Bloomington: Indiana University Press.

Lotman, Juri 2009. Culture and Explosion. (Clark, Wilma, trans.; Grishakova, Marina, ed.) Berlin: Mouton de Gruyter.

Meier-Oeser, Stephan 1997. Die Spur des Zeichens: Das Zeichen und seine Funktion in der Philosophie des Mittelalters und der frühen Neuzeit. Berlin: de Gruyter. https://doi. org $/ 10.1515 / 9783110803150$

MS = Peirce, Charles Sanders 1979 [1963-1966]. The Charles S. Peirce Papers (30 reels, 3rd microfilm edition.) Cambridge: The Houghton Library, Harvard University, Microreproduction Service. [In-text references are to MS, followed by the manuscript numbers.] 
Plato 1892. The Dialogues of Plato. Vol. 1. (Jowett, Benjamin, trans., intr.), 3rd, rev. ed. Oxford: Oxford University Press.

Sebeok, Thomas A. 2001. Global Semiotics. Bloomington: Indiana University Press.

W 5 = Peirce, Charles Sanders 1993. Writings of Charles S. Peirce: A Chronological Edition,

Vol 5: 1884-1886. Bloomington: Indiana University Press.

\section{Траектория: модель знака и семиозиса}

Рассматривается возможность применения модели траектории (путь, по которой движущий объект передвигается от точки отправления к точке назначения) в качестве адекватной модели для знаков и семиотических процессов. Знаки, как и намерения, значения и сообщения, имеют свои точки отправления и прибытия. Обращаясь к понятиям, которые в древней Греции применялись к знакам (sêma, semeîn, и tekmérion), можно заметить, что в этом раннем семиотическом словаре содержится устремленность к цели. В статье рассматривается пирсовская модель знака как траектория, посредством которого Пирс описывает «агентность знака». Семиотические траектории Пирса не имеют начала и конца. Знак, которую конечная причинность ведет к семиотической цели, может достичь ее только путем асимптоматической аппроксимации. Вторая часть статьи описывает траектории, характеризующие знаковые процессы в семиотических моделях А. Греймаса и Ю. Лотмана. Греймас различает, например, генеративные, тематические и фигуративные траектории, но прототипом всех его траекторий, является нарративная. Конфликты приводят к разветвлениям и перерывам траекторий, модель предусматривает кроме дизъюнкции и возможности конъюнкции, где траектории вливаются в одну. Лотман предлагает динамическую модель культуры как семиотического пространства, где знаковые процессы могут принять форму «взрывов» и траекторий характеризуют нелинейность, разветвление, резкие разрывы и неожиданное перенаправление. Появляются разнонаправленные траектории, которые описывают отношения между центром и периферией семиосферы.

\section{Trajektoor: märgi ja semioosi mudel}

Artiklis vaadeldakse, mil määral trajektoori kui teekonna, mida mööda liikuv objekt kulgeb lähtekohast sihtpunktini, mudel on märgi ja semiootiliste protsesside adekvaatne mudel. Nagu kavatsustel, tähendustel ja sõnumitel on ka märkidel lähtekohad ning sihtpunktid. Kui uurida mõisteid, mida vanas Kreekas kasutati, osutamaks märkidele (sêma, semềon, ja tekmérion), ilmneb, et mitmes mõttes sisaldab see varajane semiootiline sõnavara sihile suunitletust. Artiklis vaadeldakse Charles S. Peirce’i märgimudelit trajektoorina, mille kaudu Peirce kirjeldab "märgi agentsust". Peirce'i semiootilised trajektoorid on alguse ja lõputa. Märk, mida lõplik põhjuslikkus juhib semiootilise sihtmärgi poole, suudab oma sihile jõuda üksnes asümptootilise aproksimatsioonina. Artikli lõpuosas esitletakse lühimärkmeid trajektooride kohta, mis on omased märgiprotsessidele Algirdas Greimase ja Juri Lotmani visandatud semiootilistes mudelites. Greimas eristab mitmeid semiootilisi trajektoore, nt generatiivseid, temaatilisi ja figuratiivseid, kuid kõigi trajektooride 
prototüübiks on narratiivne. Konfliktsetest pingetest tekkivad hargnemised katkestavad sihtmärgile suunatud trajektooride ühesuunalisust. Lisaks disjunktsioonidele nähakse mudelis ette konjunktsioone, milles trajektoorid ühte sulavad. Dünaamilisteks jõududeks, mis lükkavad tegutsejaid (subjekte ja objekte, tegutsevaid ja passiivseid, saatjaid ja vastuvõtjaid, kangelasi ja kelme) sellistele trajektooridele liikuma on pinged ja konfliktid eri pooluste vahel ning ka iha ja selle rahuldamise faasid. Lotman pakub välja dünaamilise mudeli inimkultuurist kui semiootilisest ruumist, kus märgiprotsessid toimuvad nagu "kobrutavad hoovused" või võtavad isegi "plahvatuste" kuju, viidates trajektooridele, mida iseloomustavad mittelineaarsus, hargnemine, järsud katkestused ning ootamatu ümbersuunamine. Selliste trajektooridega kaasnevad kahesuunalised trajektoorid, mis kirjeldavad dünaamilisi suhteid kultuurilise semiosfääri tsentri ning perifeeria vahel. 